УДК 004.9:374+372.853

Сальник Ірина Володимирівна

кандидат педагогічних наук, доцент, докторант кафедри фізики та методики їі викладання Кіровоградський державний педагогічний університет імені Володимира Винниченка, Кіровоград, Україна

isalnyk@gmail.com

\title{
СУЧАСНІ ПІДХОДИ ДО ВИЗНАЧЕННЯ ВІРТУАЛЬНОГО НАВЧАЛЬНОГО СЕРЕДОВИЩА В ДИДАКТИЦІ ФІЗИКИ
}

\begin{abstract}
Анотація. Метою нашого дослідження є виявлення факторів, що впливають на розвиток сучасного навчального середовища, і виокремлення основних напрямків цього розвитку на основі взаємообумовленого і взаємопов'язаного використання віртуально й реального у процесі навчання фізики для подальшого їх використання для розробки методичної системи навчального фізичного експерименту. Проведений аналіз дозволив виокремимо ті фактори у розвитку фізичної освіти, що пов'язані з ії віртуалізацією, які, на нашу думку, істотно впливають на формування нового змісту кожного 3 компонентів педагогічної системи «процес віртуального навчання фізики» і дозволяють створити нове освітнє середовище 3 фізики.
\end{abstract}

Ключові слова: віртуальність; віртуалізація системи освіти; сучасне навчальне середовище; віртуальне навчальне середовище з фізики.

\section{1. ВСТУП}

Постановка проблеми. Нині освіта знаходиться на першому місці серед чинників розвитку людства. Роль знань в економічному розвитку країн світу нестримно зростає, витісняючи значущість засобів виробництва і природних ресурсів. Грандіозність завдань, що стоять перед освітою, і низька ефективність традиційної системи освіти примушують учених усього світу шукати не лише нові форми і методи навчання, але й нову освітню парадигму, шляхи створення нового освітнього середовища.

Розвиток інформаційних та Internet-технологій, засобів телекомунікацій справляє перетворювальний вплив на формування освітнього середовища. Отримання інформації в сучасних умовах стає життєво необхідним ресурсом, без якого неможливо досягти як навчальних і професійних цілей, так і задоволення багатьох матеріальних і культурних потреб. Завдяки новітнім технологіям змінюється роль, спосіб, швидкість та ефективність використання інформації в процесі навчання.

Одночасно створюється можливість отримання інформації і знань на відстані. Навчальне середовище вже не можна охарактеризувати за традиційною схемою, коли його учасниками $є$ або вчитель і учень, або ж учитель і група учнів. Кількість учасників окремого навчального процесу стає потенційно необмеженою.

Для характеристики сучасного навчального середовища існує значна кількість термінів і їх різних означень. Серед них: відкрите навчальне середовище (open learning environment), інформаційно-навчальне середовище, середовище дистанційного навчання (distant learning environment), інтерактивне середовище (interactive environment) та інші. Спільним для всіх цих понять $\epsilon$ те, що, здебільшого, йдеться про навчальне середовище, яке характеризується використанням мережевих й інформаційних технологій для підтримки процесу навчання.

Аналіз основних досліджень і публікацій. Оскільки комп'ютерні системи увійшли в навчальний процес досить давно (понад 30 років), то можна стверджувати, що проблемі використання інформаційних технологій у процесі навчання, зокрема 
фізики, присвячена достатня кількість наукових i науково-методичних праць i досліджень. У цих роботах розглядаються різні аспекти проблеми: організація й управління навчальною діяльністю в комп'ютерно-орієнтованому середовищі (П. С. Атаманчук, В.Ю.Биков, М. І. Жалдак); активізація пізнавальної діяльності й розвиток творчих здібностей учнів засобами IKT в процесі навчання фізики (Ю.В.Счкало, В. Е. Краснопольський., Н. П. Литкіна, А. М. Сільвейстр, I. О. Теплицький); використання комп'ютерів у самостійній роботі 3 фізики (Ю. П. Рева, Ю. О. Жук); організація навчальної діяльності у комп'ютерноорієнтованому навчальному середовищі і проектування інформаційно-освітнього

середовища (Ю. О. Жук, Ю. В. Заболотня, О. І. Іваницький, О. М. Соколюк, С.П. Стецик); проблеми оптимізації використання IКT у навчанні фізики (Л. В. Непорожня, Р. В. Майер, А. Н. Петриця, С. А. Самойлова, А. Ю. Свістунов, С. І. Телегін); використання інформаційних технологій у шкільному навчальному експерименті (С. П. Величко, В. О. Ізвозчиков, Л. М. Наконечна, Ю. М. Орищин, Н. Л. Сосницька, В. І. Сумський та ін.); формування інформатичної компетентності учнів на уроках фізики (Н. І. Баловсяк, Л. Г. Карпова, О. В. Ліскович, О. П. Пінчук, В. Д. Шарко); дистанційні технології у навчанні фізики (М. О. Моклюк) та інші.

Останнім часом з'являються дослідження, присвячені віртуалізації освіти, у яких розглядаються як позитивні, так і негативні впливи цього феномену [4]. Зокрема, наголошується, що віртуалізація освіти відкриває принципово нові можливості для розв'язання двох найважливіших і найактуальніших проблем сучасності: підвищення доступності якісної освіти (у тому числі для осіб з обмеженими фізичними можливостями); безперервності процесу освіти протягом усього людського життя, що вже сьогодні є загальновизнаною вимогою, яка проголошена в документах ЮНЕСКО (Policy Paper for Change and Development in Higher Education, 1995) і Європейського Союзу (Меморандум про безперервну освіту Комісії Свропейського Союзу від 30 жовтня 2000 р.).

У той же час слід зазначити, що віртуальна система не може бути визнана повноцінною, оскільки вона принципово не здатна повністю замінити особистий контакт учня і педагога, процеси їх особистого спілкування. Тому віртуалізація освітніх середовищ, науково обгрунтоване використання елементів технологічної системи віртуального навчання, на нашу думку, призведе до становлення принципово нової системи освіти. Будь-які спроби розвести і протиставити реальне (традиційне) i віртуальне навчання $з$ погляду основоположних принципів не повинні мати місце. Інша справа, зіставлення і порівняння цих двох форм навчання 3 погляду технології передавання знань.

3 огляду зазначеного, сучасний етап розвитку освіти характеризується не просто урізноманітненням і збільшенням кількості програмних засобів, що використовуються в навчальному процесі, а створенням особливого віртуального освітнього середовища, яке співіснує із середовищем традиційного навчання, одночасно змінюючи його, розширюючи можливості, створюючи умови реалізації нових форм і методів навчання.

Мета статті: виявлення факторів, що впливають на розвиток сучасного навчального середовища, і виокремлення основних напрямків цього розвитку на основі взаємопов' язаного використання віртуально і реального у процесі навчання фізики.

\section{2. МЕТОДИ ДОСЛІДЖЕННЯ}

Під час дослідження використовувались методи: інтерпретаційно-аналітичний, на основі якого здійснювалося вивчення, теоретичний аналіз і синтез закордонних i вітчизняних педагогічних і методичних праць, емпіричних джерел з узагальненням 
досвіду педагогічної діяльності; порівняльно-історичного аналізу, який дав змогу виявити тенденції розвитку сучасного навчального середовища й визначити його особливості в дидактиці фізики; теоретичного узагальнення, який забезпечив можливість аналізу явищ, що становлять предмет дослідження, формулювання узагальнених положень і висновків.

\section{3. РЕЗУЛЬТАТИ ДОСЛІДЖЕННЯ}

Теорія віртуальності розглядає «віртуальність» як деяку загальну характеристику самої реальності 3 погляду іiї структури і безперервного характеру такої структури, тобто континууму. Дослідники справедливо відзначають, що досягнення в економіці, політиці, науці і інших сферах усе більше залежать від образів, аніж від реальних вчинків і речей. Іншими словами, сучасне людство активно формує навколо себе новий, ілюзорний світ символів, який існує паралельно з реальним фізичним світом і стає такою ж частиною буття, як і фізична реальність [6]. А це ставить групу проблем, пов'язаних зі специфікою віртуалізації соціуму, його особливостей, а також загальних моментах віртуалізації як універсальної властивості реальності.

Саме поняття віртуальності не новина для філософії і має історію, практично порівняну з історією існування філософії. Уявлення про віртуальність у класичній фізиці, як, утім, й уявлення про віртуальні частинки у квантовій фізиці XX ст., не надали істотного впливу на соціум. Вплив ідей віртуальності став помітним із створенням комп'ютерів, інформаційних технологій, 3 появою мережі Інтернет. Входження у віртуальну реальність Інтернет, як і в інші віртуальні реальності, поза сумнівом, змінює саму людину, піi особистість. Відбувається, перш за все, зміна ідентифікації й ідентичності людини, не тільки індивідуальної, але й соціальної. Отже, тенденція віртуалізації суспільства, що розвивається, відводить людину від об'єктивної реальності.

Віртуальність в її широкому розумінні і різноманітних проявах властива в тій або іншій мірі будь-яким видам пізнавальної діяльності: науковій, філософській, художній, естетичній та ін. (І. А. Акчурін, М. Б. Садиков). 3 культурних позицій розглядається безліч віртуальних реальностей, що народжуються при дії на наші органи чуттів: музичну, віртуальність, що створюється запахами, зорова, віртуальність пов'язана 3 комп'ютерами, телебаченням, образотворчим мистецтвом (Р. А. Нуруллін). Феномен віртуальності активно обговорюється у філософській літературі як спосіб буття системних і тотальних властивостей (В. А. Кайдалов, В. А. Гаврилюк); у контексті онтологічної невизначеності, тобто спостереження того, що в реальності не спостерігається (С.С. Хоружій); у рамках категоріальних рядів «матеріальне ідеальне» (Т. А. Кирик); «можливість - дійсність» (О. В. Катаєва, Т. І. Вафін), як носій психологічного й антропологічного аспектів, при цьому оцінюються можливості віртуальної психології і віртуальної людини (Н. А. Носов, Ю. Т. Яценко); з'ясовуються можливості віртуальної реальності як форми світорозуміння (М. Д. Щелкунов); досліджуються етапи становлення віртуальної культури, культурологічні і аксіологічні аспекти віртуальності (І. А. Акчурін, Л. П. Тімофєєва); вивчається зв'язок віртуальності і творчості (Р. А. Браже); з'ясовується гносеологічна природа і методологічні функції віртуальної реальності (Б. К. Лєбєдєв); обговорюються проблеми віртуалізації реальності й евристичні аспекти віртуальної реальності (О. Е. Бакланський, С. Н. Коняєв); досліджуються уявлення про віртуальність в точних науках і віртуальні витоки життя (В. Д. Ерекаєв, К. Х. Хайруллін, Ф. Т. Валішин); обговорюється виникнення Hоmo Virtualis, людини, орієнтованої на віртуальність (Л. П. Тімофєєва); досліджується зв'язок віртуальної реальності 3 феноменом 
комп’ютеризації; конструюються концепції віртуальних технологій; оцінюються неминучі негативні впливи феномена віртуальності, зокрема, інтернетоманія й віртуальна наркоманія.

Ефекти віртуалізації реальності властиві природному процесу пізнання реальності будь-якою людиною завдяки зв'язку пізнання з реальними умовами існування людини в світі. На жаль, в Україні питаннями віртуальності займаються лише філософи і соціологи.

Множинність існуючих уявлень про феномен віртуальності, фрагментарність його дослідження, відсутність системності i цілісності у психолого-педагогічному i методичному його осмисленні приводить до необхідності його послідовного i систематичного аналізу, особливо в контексті віртуалізації системи освіти.

Віртуалізація системи освіти активно здійснюється в розвинених країнах протягом останнього десятиліття. Стимулами для цього є три основні чинники [7, c. 108]:

- підвищення вимог до рівня кваліфікації робочої сили у зв'язку 3 технологічним удосконаленням сучасного виробництва i сфери обслуговування населення;

- перехід промисловості на дрібносерійне виробництво при швидкій змінюваності моделей, що вимагає оперативної перепідготовки персоналу багатьох компаній;

- усе більше усвідомлення в суспільстві цінності якісної освіти як особистого і національного надбання.

У найбільш загальному вигляді під віртуальною освітою ми розуміємо процес $\mathrm{i}$ результат взаємодії суб'єктів і об'єктів освіти, що супроводжується створенням ними віртуального освітнього простору, специфіку якого визначають дані об'єкти і суб'єкти. Існування віртуального освітнього простору поза комунікацією вчителів, учнів та освітніх об'єктів неможливо [3].

Віртуальній освіті, на нашу думку, понад усе відповідає сферична модель, що має необмежене число ступенів свободи і не задає для кожної людини однозначного напряму руху. Центром такої сферичної моделі виступає особовий освітній потенціал людини, відносно якого і відбувається їі розвиток. Єдиний центр освіти всіх людей у такій моделі відсутній, кожна людина розвивається відповідно до своєї індивідуальної мети. Відсутній і загальний для всіх напрям освіти, кожен здійснює рух в окремих частинах своєї сфери. Склад освітньої сфери - це освітні галузі, які визначає сама людина. Розвиток (розширення) освітньої сфери відбувається нерівномірно, але в ідеалі сферична форма задає напрями для освітнього руху. Зрозуміло, що поняття «сфера», «траєкторія», «простір» i т. п. використовуються нами як педагогічні модельні уявлення, що допомагають візуалізувати модель віртуальної освіти.

Просторова модель освіти передбачає можливість створення різноманітних освітніх сфер, у яких відбуватиметься індивідуальний розвиток. Людина сама визначає свою сферу, вибудовує в ній різні структури і цінності, наповнює іiі змістом, за допомогою якого орієнтується в процесі пізнання різних освітніх галузей.

Побудова просторової моделі віртуальної освіти веде до подання внутрішнього світу людини у вигляді безлічі сфер, що розширюються: інтелектуальних, емоційнообразних, культурних, історичних, соціальних та інших. Усі вони тісно пов'язані, рухомі й утворюють в сукупності те, що можна назвати віртуальним освітнім простором людини. Цей простір здатний розширюватися в зовнішній світ. Процес розширення відбувається за допомогою діяльності учня, що використовує свої фізичні органи чуттів, емоційно-образні й інтелектуальні здібності. Віртуальний освітній простір людини розвивається у відповідному навчальному середовищі. 
Віртуальне навчальне середовище - поширений термін, на прикладі якого можна проілюструвати, що в це поняття або деякі синонімічні до нього поняття може вкладатися різний зміст. Перше тлумачення, яке пов'язується з даним терміном, полягає у тому, що під віртуальним середовищем розуміють програмне забезпечення або платформу, яка застосовується для надання освітніх послуг.

Але у поняття «віртуальне навчальне середовище» може вкладатися й інший зміст. Цей зміст узгоджується 3 тим, що наявність інформаційних і комунікаційних мереж, а також програмного забезпечення ще не $\epsilon$ достатньою. Для того щоб утворилося навчальне середовище, необхідно, щоб інформаційно-комунікаційні ресурси узгоджувалися 3 процесами комунікації і діяльності, утворюючи деяку цілісність, інтегрувалися в єдину систему, за допомогою якої підтримується i спрямовується осмислене навчання. Учні й учителі утворюють соціальну мережу, що грунтується на фізичній мережі (використовує, експлуатує іiі). Іншими словами, віртуальне освітнє середовище створюється тільки тими об'єктами і суб'єктами, які беруть участь в освітньому процесі, а не технічними засобами, наочною допомогою або учбовими аудиторіями.

Необхідно враховувати, що пізнавальна діяльність сучасного школяра здійснюється в спеціально організованому середовищі, структура й складові якого відображають рівень технологічного розвитку суспільства й ті уявлення організаторів навчального процесу, які домінують сьогодні.

Серед тенденцій розвитку і використання сучасного навчального середовища виокремимо такі:

- розвиток i поширення комп'ютерно-орієнтованих засобів навчання, що входять до складу середовища;

- зміна ролі і функцій комп'ютерних систем навчального призначення, зокрема, з елементами штучного інтелекту, у складі середовища;

- зростання ролі профільності у створенні й використанні комп'ютерних систем навчального призначення;

- зростання ролі інтеграції у створенні комп'ютерно-орієнтованих засобів навчання;

- формування віртуальних навчальних спільнот;

- поява потужних банків і бібліотек знань.

Якщо говорити про створення віртуального навчального середовища 3 фізики, то слід зауважити, що процес навчання природничо-математичних дисциплін, і зокрема фізики, є складнішим за навчання інших дисциплін, оскільки передбачає використання більшого розмаїття як організаційних форм навчального процесу, так і методів і засобів навчання. Так у педагогічній системі «процес навчання фізики» виокремлюється як підсистема дуже важлива складова «навчальний фізичний експеримент», що робить методику навчання фізики, з одного боку, більш дієвою, а з іншого, - ускладнює їі. Використання інформаційно-комунікаційних технологій й систем віртуальної реальності у навчанні фізики, на нашу думку, не лише дозволяє підвищити ефективність навчання, а й полегшує роботу вчителя.

Процес навчання фізики у віртуально орієнтованому середовищі є педагогічною системою, яка включає цільовий, змістовий, концептуальний та процесуальний компоненти. Виокремимо ті фактори у розвитку фізичної освіти, що пов'язані з іiі віртуалізацією, які, на нашу думку, істотно впливають на формування нового змісту кожного з цих компонентів і дозволяють створити нове освітнє середовище з фізики.

Цільовий компонент. Відповідно до сучасних вимог нова система освіти повинна спиратися на такі превентивні принципи: учитися жити, учитися пізнавати, учитися працювати, учитися співіснувати. Превентивна (випереджальна) система освіти має на 
меті формування у людей таких якостей, які дозволять їм успішно адаптуватися в сучасних умовах. Отже, метою навчання стає не лише опанування деякою сумою знань, а спрямування отриманих знань на розв'язання актуальних практичних і теоретичних проблем. Віртуальне навчальне середовище дозволяє учням розвивати їх інтелектуальні, творчі здібності, уміння самостійно набувати нові знання, працювати 3 різними джерелами інформації.

Змістовий компонент. У традиційному процесі навчання всі навчальні ресурси реальні, а можливість доступу до них для учнів залежить від реального часу, реального місця i реального контексту. Режим, порядок й інтенсивність навчання в даному випадку практично не залежать від учня. Наразі навчальні програми i плани традиційного навчання зорієнтовані на деякого середнього учня. Орієнтуючись, таким чином, на задоволення масового попиту, сьогоднішня система освіти просто приречена мати масу незадоволених своєю освітою людей. Вихід 3 такої ситуації відомий: навчальні програми і плани повинні стати адаптивними, легко налаштованими не тільки під запити індивідуума, але і під його освітній рівень, під динаміку його навчання Для цього, на нашу думку, якнайкраще підходять програми профільного навчання, що мають достатню варіативну складову. Можливість вибору навчальних предметів дозволить учневі завершити навчання, тобто «прийти до фінішу», власним маршрутом, отримавши той запас знань, який потрібен особисто йому для подальшого навчання відповідно до обраної майбутньої професійної діяльності. Технологія віртуального навчання найкраще підходить для досягнення цієї мети.

Віртуалізація освітніх середовищ, науково обгрунтоване використання елементів технологічної системи віртуального навчання, на нашу думку, призведе до становлення принципово нової системи освіти. Будь-які спроби розвести і протиставити реальне (традиційне) і віртуальне навчання 3 погляду основоположних принципів (таких як виховання і всебічного розвитку, науковості й посильності, свідомості і творчої активності, наочності й розвитку теоретичного мислення, системності, переходу від навчання до самоосвіти, зв'язку навчання з життям, фундаменталізації й інтеграції знань) не повинні мати місце. Тобто змістовий компонент повинен враховувати всі існуючі традиційні методики поєднуючи їх із сучасними інноваційними технологіями.

Концептуальний компонент. Виділимо ті концептуальні положення, які дозволяють конкретизувати поняття віртуального навчального середовища в дидактиці фізики.

Педагогічна система «процес навчання фізики» $є$ складним інтегративним утворенням, що постійно розвивається. Сучасні тенденції iï розвитку пов'язані 3 процесами віртуалізації системи освіти в цілому. Віртуалізація системи освіти, яка на даному етапі відчутно розвивається, відводить людину від об'єктивної реальності. У той же час посилюється необхідність використання кожним учнем навчальних досягнень 3 фізики саме у реальному об'єктивно існуючому світі. Це вимагає дослідження взаємозв'язків i взаємообумовленості у процесі навчання фізики інформаційно-комунікаційних технологій і систем віртуальної реальності поряд 3 реальними дослідами і спостереженнями учнів.

Стрімкий розвиток інформаційно-комунікаційних технологій і систем віртуальної реальності приводить до широкого запровадження їх у навчанні фізики і в системі навчального фізичного експерименту. Але фізика $\epsilon$ фундаментальною наукою, яка вивчає реальні об'єкти, явища, закони та закономірності й приклади практичного їх використання. За цих умов, використання реальних дослідів i комп'ютерного імітаційного експерименту повинні стати взаємопов' язаними і взаємодоповнюючими способами вивчення фізичного (реального) навколишнього світу, його законів i закономірностей розвитку як у методичному, так і в методологічному аспекті. Увага 
вчителя має бути звернена до встановлення співвідношення між цими видами експерименту відповідно до психологічних особливостей учнів конкретного класу i вікової групи. Поєднання у процесі навчання фізики, зокрема у системі навчального експерименту, реального i віртуального 3 урахуванням психолого-педагогічних чинників, дозволить забезпечити ефективність інноваційної моделі навчання фізики, яка передбачає випереджувальний характер розвитку особистості учня. [4, с. 97].

Сучасні тенденції розвитку фізичної освіти передбачають застосування в широкому контексті інноваційних педагогічних технологій. Найбільш перспективним, на наш погляд, є застосування в системі освіти синергетичного підходу. Синергетичний підхід і використання віртуального навчання дозволяють побачити оточуючий природній світ у всій його повноті і складності й обгрунтувати нові інтегровані підходи до його вивчення, а також вдосконалити процес навчання фізики [5].

Процесуальний компонент. Віртуалізація шкільної фізичної освіти пов’язана, у першу чергу, із застосуванням у процесі навчання інноваційних технологій і методів активного навчання. Серед інноваційних технологій комп'ютерне імітаційне моделювання можна виділити як перспективний шлях розвитку віртуального навчання фізики. Найбільш доцільними видами такого моделювання в системі навчального фізичного експерименту є моделювання мікро- i макрооб'єктів, які не можна продемонструвати реально, наприклад, рухи і взаємодії електронів, атомів та молекул, а також космічних об' єктів, і віртуальні лабораторні роботи.

Специфіка програмно-педагогічних засобів 3 фізики пов'язана із специфікою предмету. Предмет, в арсеналі якого великий комплекс символіко-графічних модельних засобів, активно використовуються фізичний експеримент i методи модельного вивчення макро- і мікрооб'єктів, обумовлює сприятливі можливості для впровадження комп'ютерного навчання, для комплексного поєднання комп'ютерного навчання 3 іншими його видами і формами, для поліфункціонального використання комп'ютерних програм, створених на основі методу імітаційного моделювання.

Окрім нових методів, у практиці навчання використовуються нові організаційні форми проведення навчальних занять, які можна поділили на віртуалізовані традиційні і віртуальні інноваційні. До першого типу занять (віртуалізованих традиційних, тобто 3 використанням інформаційно-комунікаційних технологій i засобів віртуальної реальності) відносять - традиційний урок, лекція, семінар, лабораторна робота. Заняття другого типу — це, наприклад, проектні віртуальні групи, додаткові заняття та консультації з використанням Internet-pесурсів та інші.

\section{4. ВИСНОВКИ ТА ПЕРСПЕКТИВИ ПОДАЛЬШИХ ДОСЛІДЖЕНЬ}

Отже, об’єднання усіх компонентів методичної системи навчання фізики навколо єдиної мети, яка полягає у реалізації принципів розвивального випереджувального навчання на основі взаємодії реального і віртуального, дозволить створити нове навчальне середовище й одночасно значно посилити результативність процесу навчання, запровадити сучасні підходи до навчання, реалізувати індивідуальні траєкторії розвитку особистості учнів з урахуванням рівня і профілю навчання фізики.

\section{СПИСОК ВИКОРИСТАНИХ ДЖЕРЕЛ}

1. Биков В. Ю. Теоретико-методологічні засади моделювання навчального середовища сучасних педагогічних систем / В. Ю. Биков, Ю.О.Жук // Проблеми та перспективи формування національної гуманітарної еліти : зб. наук. праць / [за ред. Л. Л. Товажнянського, О. Г. Романовського]. - Вип. 1 (5). - Харків : НТУ “ХПІ”, 2003. — С. 64-77. 
2. Колос К Р. Дидактичні вимоги до комп’ютерно орієнтованого навчального середовища закладу післядипломної педагогічної освіти [Електронний ресурс] / К. Р. Колос // Інформаційні технології та засоби навчання. - 2013. - Т. 35. - № 3. - Режим доступу до журналу : http://journal.iitta.gov.ua/index.php/itlt/article/view/834\#.U3dIgSi7JCX.

3. Сальник I. В. Віртуальність як принцип та технологія навчання / I. В. Сальник, Е. П. Сірик // Збірник наук. праць Камянець-Подільського нац. ун-ту: Інновації в навчанні фізики та дисциплін технологічної освітньої галузі: міжнародний вітчизняний досвід. Серія: педагогічна. — 2008. Вип. 14. - 226 с. - С. $158-160$.

4. Сальник І. В. Психолого-педагогічні основи віртуального навчання фізики в старшій школі / I. В. Сальник //Зб. наукових праць: Педагогічний процес: теорія і практика. Вип. 1. — К. :ТОВ «Видавниче підприємство «ЕДЕЛЬВЕЙС»», 2014. — С. 92-99.

5. Сальник И. В. Развитие системы учебного физического эксперимента на основе синергетического подхода / И. В. Сальник // Материалы XIII Международной научно-практической конференции «Физическое образование: проблемы и перспективы развития»: Часть 1. — М. : МГПУ, 2014. — С. 75-78.

6. Добронравова I. Філософія освіти за доби постнекласичної науки / Ірина Добронравова // Філософія освіти. — 2005. - № 1. - С. 116-125.

7. Цикін В. О. Філософія освіти - стратегія прориву в майбутнє : монографія / В. О. Цикін, І. А Бріжата. - Суми : СумДПУ ім. А. С. Макаренка, 2012. - 258 с.

Матеріал надійшов до редакиї 17.03.2014 p.

\title{
СОВРЕМЕННЫЕ ПОДХОДЫ К ОПРЕДЕЛЕНИЮ ВИРТУАЛЬНОЙ УЧЕБНОЙ СРЕДЫ В ДИДАКТИКЕ ФИЗИКИ
}

\author{
Сальник Ирина Владимировна \\ кандидат педагогических наук, доцент, докторант кафедры физики и методики её преподавания \\ Кировоградский государственный педагогический университет имени Владимира Винниченко, \\ г. Кировоград, Украина \\ isalnyk@gmail.com
}

\begin{abstract}
Аннотация. Целью нашего исследования является выявление факторов, влияющих на развитие современной учебной среды и выделение основных направлений этого развития на основе взаимосвязанного использования виртуального и реального в процессе обучения физике для дальнейшего их использования при разработке методической системы учебного физического эксперимента. Проведенный анализ позволил выделить те факторы в развитии физического образования, связанные с его виртуализацией, которые, по нашему мнению, существенно влияют на формирование нового содержания каждого из компонентов педагогической системы «процесс виртуального обучения физики» и позволяют создать новую образовательную среду по физике.
\end{abstract}

Ключевые слова: виртуальность; виртуализация системы образования; современная учебная среда; виртуальная учебная среда по физике.

\section{MODERN APPROACHES TO VIRTUAL LEARNING ENVIRONMENTS IN DIDACTICS OF PHYSICS}

\section{Iryna V. Salnyk}

PhD (pedagogical sciences), assistant professor, doctoral student of the Department of physics and methods of its teaching

Kirovohrad Volodymyr Vynnychenko State Pedagogical University, Kirovohrad, Ukraine isalnyk@gmail.com
Abstract. The aim of our research is to identify the factors that influence on the development of modern learning environment and to draw the main lines of the development through interconnected use of virtual and real in teaching process of physics and for later use of them in the development of educational methodical physical experiment. The analysis allowed to 
distinguish those factors in the development of physical education, which related to its virtualization, which, in our opinion, significantly affect on the formation of new content of each component of educational systems' virtual learning process of physics and allow you to create a new learning environment of physics.

Keywords: virtual; virtualization of the education system; modern learning environment; virtual learning environment of physics.

\section{REFERENCES (TRANSLATED AND TRANSLITERATED)}

1. Bykov V. Yu. Theoretical and methodological basis of simulation learning environment of modern educational systems / V. Yu. Bykov, Yu. O. Zhuk// Problemy ta perspektyvy formuvannya natsional'noyi humanitarnoyi elity : zb. nauk. prats' / [za red. L. L. Tovazhnyans'koho, O. H. Romanovs'koho]. — Vyp. 1 (5). — Kharkiv : NTU “KhPI”, 2003. — S. 64-77 (in Ukrainian).

2. Kolos K. R. Teaching requirements for computer-based learning environment post-graduate teacher education [online] / K. R. Kolos // Informatsiini tekhnolohii i zasoby navchannia. — 2013. - $\quad$ T. $35 . \quad$ - $\quad$ № 3. $\quad-\quad$ Available from : http://journal.iitta.gov.ua/index.php/itlt/article/view/834\#.U3dIgSi7JCx (in Ukrainian).

3. Salnyk I. V. Virtuality as a principle and technology education / I. V. Salnyk, E. P. Siryk // Zbirnyk nauk. prats Kamyanets-Podilskoho nats. un-tu: Seriya: pedahohichna: Vyp. 14: Innovatsiyi $\mathrm{v}$ navchanni fizyky ta dystsyplin tekhnolohichnoyi osvitnoyi haluzi: mizhnarodnyy vitchyznyanyy dosvid. - K.-Pod., 2008. - S. 158-160 (in Ukrainian).

4. Salnyk I. V. Psychological and pedagogical basis of teaching physics virtualization in senior school / I. V. Salnyk// Zb. naukovykh prats': Pedahohichnyy protses: teoriya i praktyka.: Vyp.1. — K. :TOV «Vydavnyche pidpryyemstvo «EDEL'VEYS»», 2014. - S. 92-99 (in Ukrainian).

5. Salnyk I. V. Development of the system of educational physical experiment based on a synergistic approach / I. V. Salnyk// Materialyi XIII Mezhdunarodnoy nauchno-prakticheskoy konferentsii «Fizicheskoe obrazovanie: problemyi i perspektivyi razvitiya»: Chast 1. — M. : MGPU, 2014. — S. 75-78 (in Russian).

6. Dobronravova I. Philosophy of education in the era of science Postnonclassical / I. Dobronravova // Filosofiya osvity. — 2005. — № 1. - S. 116-125 (in Ukrainian).

7. Tsykin V. O. Philosophy of Education - a breakthrough strategy for the future / V. O. Tsykin, I. A. Brizhata: monohrafiya. - Sumy : SumDPU im. A. S. Makarenka, 2012. - 258 s. (in Ukrainian). 